GLOBAL JOURNAL OF PURE AND APPLIED SCIENCES VOL. 22, 2016: 1-5 COPYRIGHT@ BACHUDO SCIENCE CO. LTD PRINTED IN NIGERIA ISSN 1118-0579

\title{
IMPACT OF CEMENT DUST POLLUTION ON RESPIRATORY SYSTEMS OF LAFARGE CEMENT WORKERS, EWEKORO, OGUN STATE, NIGERIA
}

\author{
M. N. CHUKWU AND N. I. UBOSI \\ (Received 28 January 2016; Revision Accepted 10 June 2016)
}

\begin{abstract}
In this investigation, the impact of cement dust pollution on respiratory systems of Lafarge cement workers was evaluated. A total of 120 respondents; 60 from the factory workers and 60 (controls) from lfo, a nearby village $22 \mathrm{~km}$ NE of the factory were interviewed in 2014 using a modified respiratory symptom score questionnaire. Two hypotheses were formulated in null form and tested at $95 \%$ probability level. Descriptive statistics, independent and dependent $t$-tests were used to compare treatments while Analysis of variance (ANOVA) and Scheffe multiple comparisons were used for comparing groups. Results indicated that there were no significant differences in the rate of breathlessness and wheezing, cough, chest illnesses and past illnesses between factory workers and controls. There were however significant differences in rates of breathlessness and wheezing, and past illnesses between workers in packing section and other sections of the factory. The study recommended that the government should look into the welfare of lafarge cement workers to ensure that additional and adequate safety devices are provided to the factory workers.
\end{abstract}

KEYWORDS: Cement dust, pollution, respiratory systems, illnesses, packing section.

\section{INTRODUCTION}

Pollutants released from industries are the major source of environmental pollution. Cement production is a dusty operation leading to the exposure of factory workers to cement dust. The pollutants in the cement industry are emitted from the various production processes such as crushing, blending, storage and packing (Al Neaimi et al, 2001). Higher dust concentrations have been reported in the crushing and packing sections than in other sections (Mwaiselage et al, 2005).

Airborne respirable dust measuring from less than 5 to more than 40 milligrams per meter cube $(\mathrm{mg} / \mathrm{m}$ ${ }^{3}$ ) have been recorded in the work place of cement factory workers. The aerodynamic diameter of the cement dust ranges from 0.05 to 20 micro meter ( $\mathrm{m}$ ). Their small size makes the whole respiratory tract a target for cement dust deposition (Mwaiselage et al, 2005).

Cement dust is a mixture of Calcium, Potassium, Silicon and Sodium which often include heavy metals like Aluminium, Cadium, Lead, Zinc, Iron and Chromium which in excess are hazardous to the environment with impact on human health (Gbadebo and Bankole, 2007, Baby et al, 2008 and Kumar et al, 2008). The most frequently reported health problems among cement mill workers are chronic cough and phlegm production (Dietz et al, 2004 and Meo, 2004). Cement dust also irritate the skin, mucous membrane of the eyes and the respiratory system in general. The deposition of cement dust in the respiratory tract leads to increased $\mathrm{pH}$ values which irritate the exposed mucous membranes and impair respiration (Mwaiselage et al., 2005, Fell et al., 2003, Aydin et al., 2010 and Zeleke et al., 2010).

Al Neaimi et al (2001) however, documented that regular use of appropriate personal protective equipment at the work site could protect the cement factory workers from adverse health effects.

Cement Workers in Nigeria are often from lower socioeconomic class and are frequently hired without appropriate training and deployed at work sites without proper personal protective equipment or ventilation (Al Neaimi et al, $2001 \mathrm{Meo}$ et al. (2002). They also opined that the level of awareness about occupational hazards among factory workers in Nigeria is low, thus, how working in highly dusty environments affects health and safety is a serious concern. The factory workers do not adequately protect themselves thoroughly with personal protective device due to ignorance or non-availability of personal protective devices and this has led to the prevalence of respiratory tract diseases among them.

\section{Objectives of the Research}

The objectives of the study include:

i. To ascertain the impact of cement dust pollution on respiratory systems of Lafarge cement workers, Ewekoro, Ogun state, Nigeria.

\footnotetext{
M. N. Chukwu, Biology Unit, School of Science and Technology, National Open University of Nigeria, Lagos, Nigeria.

N. I. Ubosi, Public health Unit, School of Health Sciences, National Open University of Nigeria, Lagos, Nigeria.
} 
ii. To identify the most hazardous section of the factory.

iii. To obtain base line information that will be used to develop a good air pollution control device to proffer solution to the adverse effects of cement dust pollution on the respiratory systems of the workers.

\section{Research Questions}

RQ1: What is the impact of cement dust pollution on respiratory system of Lafarge cement workers?

RQ2: Which section of the factory is most hazardous?

\section{Research Hypothesis}

$\mathbf{H}_{0}$ 1: There is no significant difference in the prevalence of respiratory symptoms and illnesses between cement factory workers and the controls.

$\mathbf{H}_{0}$ 2: There is no significant difference in the prevalence of respiratory symptoms and illnesses among workers in different sections of the factory.

\section{Methodology}

A sample of 60 factory workers was selected; 20 workers each who had worked in the crushing, packing and blending sections for at least 5 years using purposive sampling. The workers in these sections were selected because of their high level of exposure to cement dust. Equal number of unexposed people who are not exposed to cement dust in the past were also randomly selected from a nearby town; Ifo, $22 \mathrm{~km}$ NE of the factory and used as controls. These controls matched for age and socio-economic status with the exposed population. Data were collected through observations and personal interviews using a modified respiratory symptom score questionnaire, titled "Respiratory questionnaire for Adults". The first section of the questionnaire focused on some demographic data of the respondents. The second part had 26 Likert type items designed to assess the Respiratory system impact. This include functions aimed to indicate never (1), mild (2), moderate (3), severe (4) or very severe (5) (Zeleke et al, 2010).

Statistical Package for the Social Sciences (SPSS) version 20.0 for Windows was used for statistical analysis. $P<0.05$ was used as the criterion for statistical significance. Descriptive statistics, independent and dependent $t$-tests were used to compare treatments. Analysis of variance (ANOVA) and Scheffe multiple comparisons were used for comparing groups.

\section{RESULTS}

Figure 1 shows the percentage of the factory workers and controls with various respiratory symptoms and illnesses, Totals of 60 cement factory workers and 60 controls were interviewed. Out of 60 factory workers, $22(40.74 \%)$ had breathlessness and wheezing compared to $16(29.63 \%)$ controls. Among the factory workers, $35.71 \%, 20.69 \%$ and $13.79 \%$ had cough, chest illnesses and past illnesses respectively in contrast to $25 \%, 13.79 \%$ and $10.34 \%$ in the controls (Fig. 1 ).

Figure 2 shows the distribution of respondents with respiratory symptoms and IIInesses in the crushing, packaging and blending sections of the factory. Worker from the packing section recorded about double the percentages from other sections for all respiratory symptoms and illnesses except for chest illnesses where workers from the crushing section recorded a slightly higher percentage. Workers from both crushing and blending sections recorded almost equal percentage prevalence for all symptoms and disease.

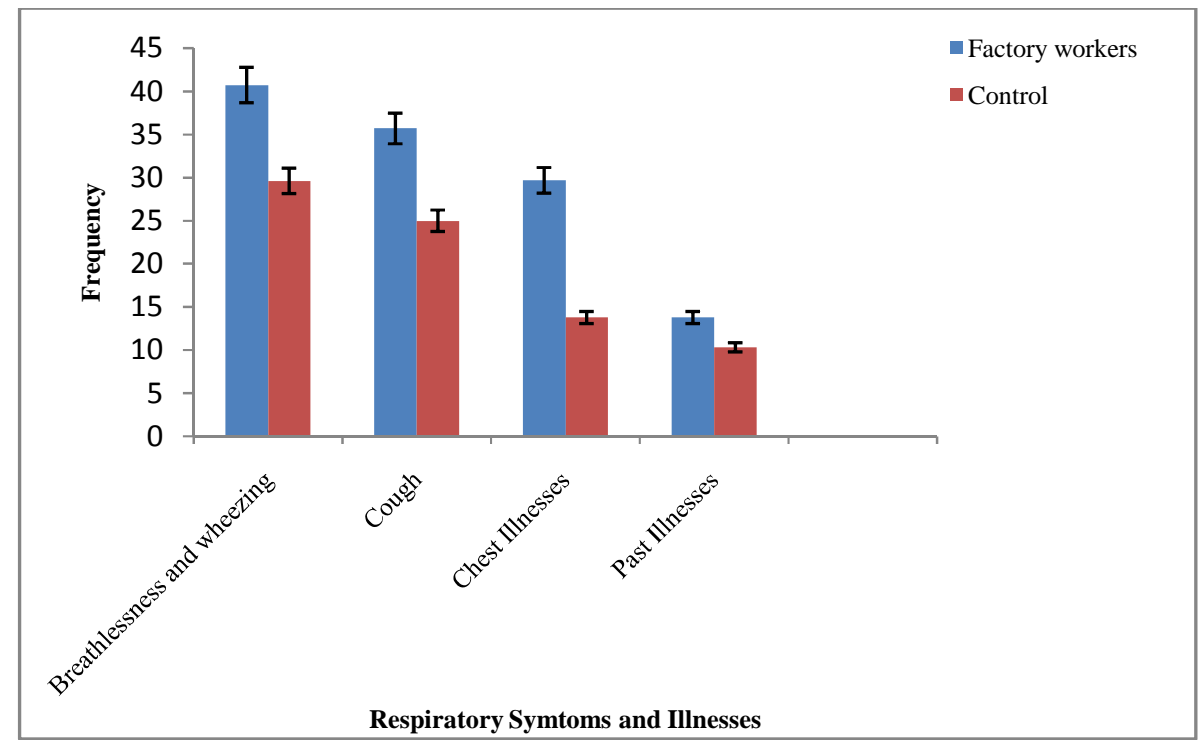

Fig. 1: Distribution of respondents with respiratory symptoms and Illnesses. Values shown are Mean \pm SE 


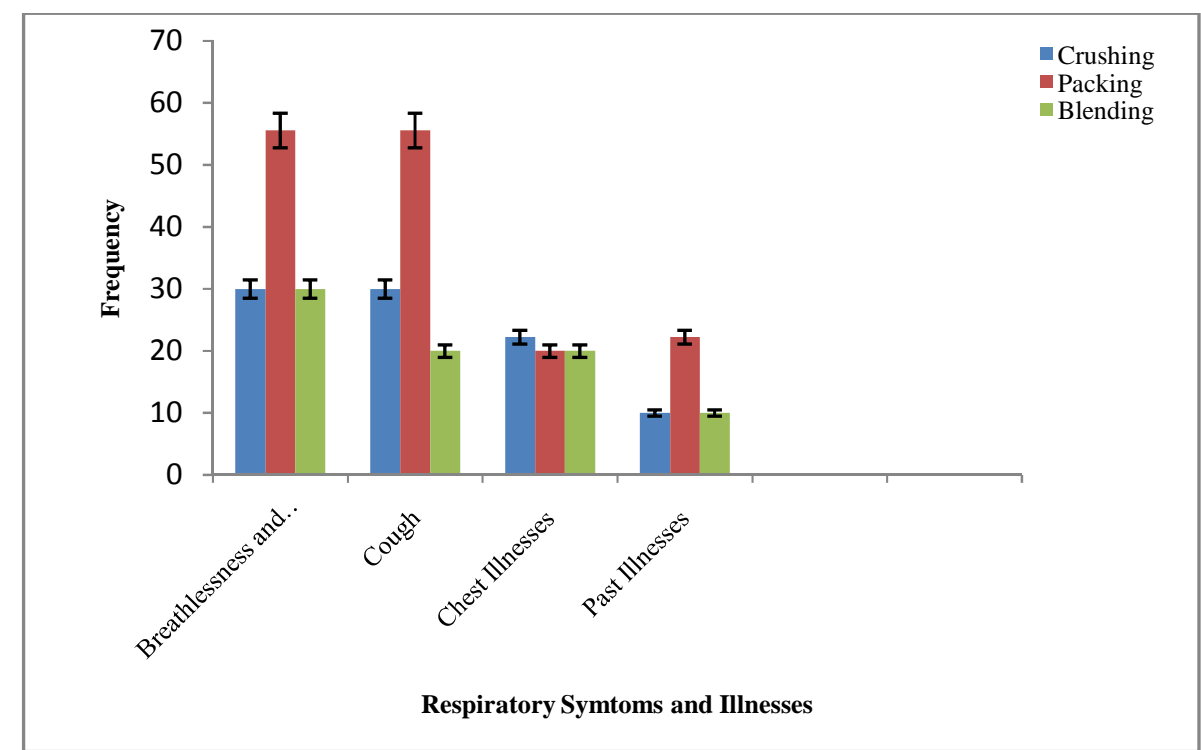

Fig. 2: Distribution of respondents with respiratory symptoms and Illnesses in different sections of the factory. Values shown are Mean \pm SE

The factory workers are more susceptible to respiratory symptoms and illnesses. However, the results of the paired t-test in Table 1 showed that the two tailed $t$ values computed for all the respiratory symptoms and illnesses tested are all more than 0.05 .
To this end we accept the hypothesis that there is no significant difference in the prevalence of respiratory symptoms and illnesses between cement factory workers and the controls.

Table 1: Paired t-test for the differences in the prevalence of respiratory symptoms and illnesses between factory workers and controls

\begin{tabular}{|ll|l|l|l|l|l|l|}
\hline Treatment & & Sum & Mean & $\begin{array}{l}\text { Standard } \\
\text { Deviation }\end{array}$ & $\mathrm{t}$ & $\begin{array}{l}\text { Degree of } \\
\text { freedom }\end{array}$ & $\begin{array}{l}\text { Significance } \\
\text { (two tailed) }\end{array}$ \\
\hline Breathlessness: & Factory workers & 60 & 4.80 & 3.188 & 1.88 & 118 & 0.370 \\
and wheezing: & Controls & 60 & 3.97 & 3.917 & & & \\
\hline Cough: & $\begin{array}{l}\text { Factory workers } \\
\text { Controls }\end{array}$ & 60 & 2.80 & 2.058 & 0.902 & 118 & 0.169 \\
\hline Chest illnesses: & $\begin{array}{l}\text { Factory workers } \\
\text { Controls }\end{array}$ & 60 & 2.03 & 2.205 & & & \\
\hline Past illnesses: & $\begin{array}{l}\text { Factory workers } \\
\text { Controls }\end{array}$ & 60 & 4.47 & 0.774 & 0.914 & 118 & 0.182 \\
& 60 & 0.67 & 1.484 & 3.266 & 118 & 0.108 \\
\hline
\end{tabular}

Tables $2 a$ and $b$ compared the differences in the prevalence of respiratory symptoms and illnesses among workers in different sections of the factory. From Table 2a, the significance value is less than 0.05 for breathing and wheezing and also for past illnesses depicting significance difference between and within groups. Table $2 \mathrm{~b}$ on the other hand showed a significant difference between the packing and other sections of the factory for the symptoms and diseases mentioned above. Hence we reject the hypothesis that there is no significant difference in the prevalence of respiratory symptoms and illnesses among workers in different sections of the factory. 
Table 2a: ANOVA for the differences in the prevalence of respiratory symptoms and illnesses among workers in different sections of the factory

\begin{tabular}{|c|c|c|c|c|c|c|}
\hline & & $\begin{array}{l}\text { Sum of } \\
\text { Squares }\end{array}$ & $\begin{array}{l}\text { Degree of } \\
\text { freedom }\end{array}$ & $\begin{array}{l}\text { Mean } \\
\text { square }\end{array}$ & $\mathrm{F}$ & Significance \\
\hline $\begin{array}{l}\text { Breathlessness } \\
\text { and wheezing }\end{array}$ & $\begin{array}{l}\text { Between Groups } \\
\text { Within Groups } \\
\text { Total }\end{array}$ & $\begin{array}{l}109.400 \\
185.400 \\
294.800\end{array}$ & $\begin{array}{r}2 \\
57 \\
59\end{array}$ & $\begin{array}{r}54.700 \\
6.867\end{array}$ & 7.966 & 0.002 \\
\hline Cough & $\begin{array}{l}\text { Between Groups } \\
\text { Within Groups } \\
\text { Total }\end{array}$ & $\begin{array}{r}13.400 \\
109.400 \\
122.800\end{array}$ & $\begin{array}{r}2 \\
57 \\
59\end{array}$ & $\begin{array}{l}6.700 \\
4.052\end{array}$ & 1.654 & 0.210 \\
\hline Chest Illnesses & $\begin{array}{l}\text { Between Groups } \\
\text { Within Groups } \\
\text { Total }\end{array}$ & $\begin{array}{r}1.867 \\
15.500 \\
17.367\end{array}$ & $\begin{array}{r}2 \\
57 \\
59\end{array}$ & $\begin{array}{l}0.933 \\
0.574\end{array}$ & 1.626 & 0.215 \\
\hline Past Illnesses & $\begin{array}{l}\text { Between Groups } \\
\text { Within Groups } \\
\text { Total }\end{array}$ & $\begin{array}{l}12.867 \\
51.000 \\
53.867\end{array}$ & $\begin{array}{r}2 \\
57 \\
59\end{array}$ & $\begin{array}{l}6.433 \\
1.889\end{array}$ & 3.402 & 0.048 \\
\hline
\end{tabular}

Table 2b: Scheffe multiple comparison of the differences in the prevalence of respiratory symptoms and illnesses among workers in different sections of the factory

\begin{tabular}{|c|c|c|c|c|c|c|c|}
\hline & \multirow{2}{*}{$\begin{array}{l}\text { Mean } \\
\text { Difference } \\
(\mathrm{I}-\mathrm{J})\end{array}$} & \multirow[b]{2}{*}{$\begin{array}{l}\text { Standard } \\
\text { Error }\end{array}$} & \multirow[b]{2}{*}{ Significance } & \multicolumn{2}{|c|}{ 95\% Confidence Interval } \\
\hline & & & & & & $\begin{array}{l}\text { Lower } \\
\text { Boundary } \\
\end{array}$ & $\begin{array}{l}\text { Upper } \\
\text { boundary }\end{array}$ \\
\hline \multirow{5}{*}{$\begin{array}{l}\text { Breathessnesss } \\
\text { and wheezing }\end{array}$} & \multirow{3}{*}{$\begin{array}{l}\text { Packing } \\
\text { Crushing }\end{array}$} & \multirow{5}{*}{$\begin{array}{l}\text { Crushing } \\
\text { Blending } \\
\text { Packing } \\
\text { Blending } \\
\text { Packing } \\
\text { Crushing } \\
\end{array}$} & $\begin{array}{l}4,000^{*} \\
4100^{*}\end{array}$ & $\begin{array}{l}1.172 \\
1172\end{array}$ & $\begin{array}{l}0.008 \\
0.006\end{array}$ & $\begin{array}{l}0.96 \\
1.06\end{array}$ & $\begin{array}{l}7.04 \\
714\end{array}$ \\
\hline & & & $-4.000^{\star}$ & 1.172 & 0.008 & -7.04 & -0.96 \\
\hline & & & -0.100 & 1.172 & 0.996 & -2.94 & 3.14 \\
\hline & \multirow[t]{2}{*}{ Blending } & & $-4.100^{\star}$ & 1.172 & 0.006 & -7.14 & -1.06 \\
\hline & & & -0.100 & 1.172 & 0.996 & -3.14 & 3.94 \\
\hline \multirow[t]{3}{*}{ Cough } & \multirow{2}{*}{$\begin{array}{l}\text { Packing } \\
\text { Crushing }\end{array}$} & \multirow{3}{*}{$\begin{array}{l}\text { Crushing } \\
\text { Blending } \\
\text { Packing } \\
\text { Blending } \\
\text { Packing } \\
\text { Crushing }\end{array}$} & $\begin{array}{l}1.600 \\
1.100\end{array}$ & $\begin{array}{l}0.900 \\
0.900\end{array}$ & $\begin{array}{l}0.225 \\
0.484\end{array}$ & $\begin{array}{l}-0.73 \\
-1.23\end{array}$ & $\begin{array}{l}3.93 \\
3.43\end{array}$ \\
\hline & & & $\begin{array}{r}-1.600 \\
-0.500\end{array}$ & $\begin{array}{l}0.900 \\
0.900\end{array}$ & $\begin{array}{l}0.225 \\
0.858\end{array}$ & $\begin{array}{l}3.93 \\
2.83\end{array}$ & $\begin{array}{l}0.73 \\
1.83\end{array}$ \\
\hline & Blending & & $\begin{array}{r}-1.100 \\
0.500\end{array}$ & $\begin{array}{l}0.900 \\
0.900\end{array}$ & $\begin{array}{l}0.484 \\
0.858\end{array}$ & $\begin{array}{l}-3.43 \\
-1.83\end{array}$ & $\begin{array}{l}1.23 \\
3.83\end{array}$ \\
\hline \multirow[t]{3}{*}{ Chest illnesses } & \multirow{2}{*}{$\begin{array}{l}\text { Packing } \\
\text { Crushing }\end{array}$} & \multirow{3}{*}{$\begin{array}{l}\text { Crushing } \\
\text { Blending } \\
\text { Packing } \\
\text { Blending } \\
\text { Packing } \\
\text { Crushing }\end{array}$} & $\begin{array}{l}0.600 \\
0.400\end{array}$ & $\begin{array}{l}0.339 \\
0.339\end{array}$ & $\begin{array}{l}0.227 \\
0.507\end{array}$ & $\begin{array}{l}-0.28 \\
-0.48\end{array}$ & $\begin{array}{l}1.48 \\
1.28\end{array}$ \\
\hline & & & $\begin{array}{l}-0.600 \\
-0.200\end{array}$ & $\begin{array}{l}0.339 \\
0.339\end{array}$ & $\begin{array}{l}0.227 \\
0.841\end{array}$ & $\begin{array}{l}-1.48 \\
-1.08\end{array}$ & $\begin{array}{l}0.28 \\
0.68\end{array}$ \\
\hline & Blending & & $\begin{array}{r}-0.400 \\
0.200 \\
\end{array}$ & $\begin{array}{l}0.339 \\
0.339 \\
\end{array}$ & $\begin{array}{l}0.507 \\
0.841\end{array}$ & $\begin{array}{l}-1.28 \\
-0.68 \\
\end{array}$ & $\begin{array}{l}0.48 \\
1.08 \\
\end{array}$ \\
\hline \multirow[t]{3}{*}{ Past illnesses } & \multirow{2}{*}{$\begin{array}{l}\text { Packing } \\
\text { Crushing }\end{array}$} & \multirow{3}{*}{$\begin{array}{l}\text { Crushing } \\
\text { Blending } \\
\text { Packing } \\
\text { Blending } \\
\text { Packing } \\
\text { Crushing }\end{array}$} & $\begin{array}{l}1.600^{*} \\
0.900 \\
\end{array}$ & $\begin{array}{l}0.615 \\
0.615\end{array}$ & $\begin{array}{l}0.049 \\
0.356 \\
\end{array}$ & $\begin{array}{r}0.01 \\
-0.69 \\
\end{array}$ & $\begin{array}{l}3.19 \\
2.49 \\
\end{array}$ \\
\hline & & & $\begin{array}{l}-1.600^{*} \\
-0.700 \\
\end{array}$ & $\begin{array}{l}0.615 \\
0.615\end{array}$ & $\begin{array}{l}0.049 \\
0.531\end{array}$ & $\begin{array}{l}-3.19 \\
-2.29 \\
\end{array}$ & $\begin{array}{r}-0.01 \\
0.89 \\
\end{array}$ \\
\hline & Blending & & $\begin{array}{r}-0.900 \\
0.700 \\
\end{array}$ & $\begin{array}{l}0.615 \\
0.615\end{array}$ & $\begin{array}{l}0.356 \\
0.531\end{array}$ & $\begin{array}{r}-2.49 \\
0.89 \\
\end{array}$ & $\begin{array}{l}0.69 \\
0.229\end{array}$ \\
\hline
\end{tabular}

\section{DISCUSSION}

There is variation in the prevalence of respiratory symptoms and illnesses between the factory workers and the control. There were no significant differences in the major confounding variables of age and socio-economic status, thus any increased prevalence of respiratory symptoms and illnesses would invariable be attributed to the presence of the cement dust. The fact that the factory workers recorded higher percentages for all respiratory symptoms and illness was due to the presence of the cement dust pollutant. This is in agreement with the findings of Al Neaimi et al. (2001) and Meo et al. (2002) that the resulting exposure to cement dust has led to impairment of respiration and a high prevalence of respiratory symptoms amongst workers.

Respiratory symptoms and illnesses were most prevalent among workers from the packing section of the factory compared with those from the crushing and blending sections. As earlier mentioned breathlessness and wheezing and also past illnesses were significantly different in the workers from the packing section compared with others. This is congruent to the findings of Mwaiselage et al. (2005) who reported higher dust concentrations in the crushing and packing sections than in other sections.

Data and information presented in this study will be useful in developing a good air pollution control device to proffer solution to the adverse effects of 
cement dust pollution on the respiratory systems of the factory workers.

\section{CONCLUSION/RECOMMENDATION}

The findings of this study showed that cement dust cause respiratory symptoms and illnesses amongst the factory workers. There is need to enlighten the factory workers on the dangers associated with cement dust pollution. The government should thus look into the welfare of workers of lafarge cement workers to ensure that additional and adequate safety devices are provided for the factory workers.

\section{REFERENCES}

Al-Neaimi, Y. I., Gomes, J and Lloyd, O. L., 2001. Respiratory illnesses and ventilatory function among workers at a cement factory in a rapidly developing country. Occup. Med. 51, (6):367373.

Aydin, S., Aydin, S., Croteau, G., I. Sahin, I and Citil, C., 2010. "Ghrelin, Nitrite and Paraoxonase/Arylesterase Concentrations in Cement Plant Workers. Journal of Medical Biochemistry. 29, (2): 78-83.

Baby, S., Singh, N. A., Shrivastava, P., Nath, S. R., Kumar, S. S., Singh, D and Vivek, K., 2008. Impact of dust emission on plant vegetation of vicinity of cement plant. Environ. Eng. Manage. J. 7, (1): 31 - 35.

Dietz, A., Ramroth, H., Urban, T., Ahrens, W and Becher, H., 2004. "Exposure to cement dust, related Occupational groups and laryngeal cancer risk:
Results of a population based case- control study". Intl. J. of Cancer. 108, (6): 907 - 911.

Fell, A. K. M., Thomassen, T. R., Kristensen, P., Egeland, $T$ and Kongerud, J., 2003. Respiratory symptoms and ventilatory function in workers exposed to Portland cement dust. J. of Occup. Environ. Med. 45, (9):1008-1014.

Gbadebo, A. M and Bankole, O. D., 2007. Analysis of Potentially Toxic Metals in Airborne Cement Dust around Sagamu, Southwestern Nigeria. Journal of Applied Sciences. 7, (1): 35 - 40.

Kumar, S. S., Singh, N. A., Kumar, V., Sunisha, B., Preeti, S., Deepali, S and Nath, S. R., 2008. Impact of dust emission on plant vegetation in the vicinity of cement plant. Environmental Engineering and Management Journal. 7, (1): 31-35.

Meo, S. A., 2004. "Health hazards of cement dust". Saudi Med. Journal. 25, (9): 1153 - 1159.

Meo, S. A., Azeem, M. A., Ghori, G. M and Subhan M. M., 2002. Lung function and surface electromyography of intercostal muscles in cement mill workers. Int'l. J. of Occup.Med. and Envt. Health 15, (3): 279-287.

Mwaiselage, J., Bratveit, M., Moen, B. and Mashalla, Y., 2005. Variability in dust exposure in a Cement factory in Tanzani. Ann. Occup. Hyg. 49, (6): 511-519.

Zeleke, Z., Moen, B and Bratveit, M., 2010. Cement dust exposure and acute lung function: A cross shift study. British Medical Council Publication.10, (1):19. 